\title{
Dentistry teachers and the Burnout Syndrome
}

\section{A docência em Odontologia e a Síndrome de Burnout}

\author{
Miriane Lucindo ZUCOLOTO \\ Undergraduate Student - School of Dentistry of Araraquara - UNESP - Univ Estadual Paulista - \\ Araraquara - SP - Brazil.
}

João MAROCO

Phd Associated Professor - UIPES - Psychology and Health Research Unit I\&D - ISPA-IU - Lisboa Portugal.

\section{Juliana Alvares Duarte Bonini CAMPOS}

Phd Associated Professor - Biostatistics and Scientific Methodology - Department of Social Dentistry - School of Dentistry of Araraquara - UNESP - Univ Estadual Paulista - Araraquara - SP - Brazil.

\begin{abstract}
ABSTR ACT
The Burnout Syndrome is considered a psychosocial problem to which teachers are routinely exposed. This study was conducted to estimate the prevalence of burnout in Dentistry teachers and its relation to relevant socio-demographic variables. The participants were 70 teachers from the undergraduate Dentistry Course, Faculty of Dentistry of Araraquara - UNESP. Oldenburg Burnout Inventory (OLBI) was used. The prevalence of burnout was estimated. In order to compare mean scores of burnout dimensions for each variable of interest Student's $t$ tests, for a significance level of $5 \%$, were performed. Mean age of participants was $46.0 \pm 6.1$ and teaching experience was $19.6 \pm 7.6$ years. The prevalence of burnout was 17.1\%. Low mean scores for Exhaustion (2.11 \pm 0.61$)$ and Disengagement (1.73 \pm 0.50$)$ were observed. There were statistically significant differences in the exhaustion dimension between genders $(\mathrm{p}=0.049)$, for participants who reported taking medication due to work $(\mathrm{p}=0.008)$ and for those who have thought about quit teaching $(\mathrm{p}=0.001)$. There was no statistically significant difference between Exhaustion scores as to teaching experience and also Disengagement scores according to the habit of taking medication, the experience as a teacher and gender.
\end{abstract}

KEYWORDS

Occupational health; burnout syndrome; dentistry; faculty; public health.

\section{INTRODUCT ION}

The burnout syndrome is considered a psychosocial problem that directly affects professionals' quality of life from several fields.

There are a number of concepts attributed to burnout in literature. The most widely accepted definition for the syndrome is that of Maslach and Jackson [1] who characterize it as a reaction to multifactorial and chronic emotional stress, consisting mainly of emotional exhaustion. According to the authors, exhaustion is the basic component of burnout understanding. Workload and intrapersonal conflict are among the main reasons for this exhaustion; however, added to this condition, depersonalization and low personal accomplishment regarding work also occur. Depersonalization is a negative reaction characterized by indifference to work, also called dehumanization; low achievement refers to the sense of incompetence that may have as consequence low 
productivity and lack of motivation in daily tasks performance.

The initial research on burnout syndrome was developed with professionals who, due to the nature of their work, needed to maintain direct, often and emotional contact with their clients. Take, as example, health care, social services and education professionals. However, nowadays the concept is part of a broader perspective and extends to a diversity of professional and occupational groups [2].

Research about the burnout syndrome in teachers has been presented in international literature, given that it is a profession routinely exposed to predisposing psychosocial factors for the occurrence of this syndrome in a workplace. The studies about working conditions and teachers health in Brazil are relatively recent when compared to other occupational categories.

According to Carlotto [3], teachers are often exposed to psychosocial risks such as aggression, interpersonal conflicts, overload of cases to address, role conflict, ambiguity, perceptions of inequity in social exchange, and lack of control over results. According to the author, these factors, added to individual's inability to deal with them, may increase the risk for developing burnout syndrome.

Health professionals are also included in the group of workers directly exposed to factors that may lead to the development of professional stress. However, few studies refer to the combination of teaching and clinical work of faculty members in health sciences. According to Chambers [4] and Griffith [5] this union of roles and responsibilities can be harmful by increasing stress levels related to low autonomy, overload work and the challenges of both areas.

Thus, taking these studies into account, and given the lack of research on Burnout in health courses faculty members, as well as the need to detect its prevalence and associated symptoms, we propose this study in order to estimate this syndrome prevalence in professors of an undergraduate degree in Dentistry.

\section{Materials and Methods}

\section{Study population}

All professors from Faculty of Dentistry Araraquara / UNESP - (except substitute teachers and those hired for less than three years), were invited to participate in the study. The study population was 99 teachers. 71 of them agreed to participate.

\section{Study Variables}

To characterize the sample, socio-demographic information such as gender, age, time from graduation, teaching time, working conditions, facilities, materials and equipment, use of medication due to work, and teachers thoughts about quitting, was considered.

The burnout syndrome was assessed using Oldenburg Burnout Inventory (OLBI) [6]. It is important to clarify that inventories were anonymous. This instrument was originally proposed in German, and consists of 16 items, with a four-point Likert-type response scale, divided into two dimensions - Exhaustion and Disengagement; four items of each dimension are positive statements and four are negative. In this study we used a Portuguese version developed by Campos et al. [7], taking into consideration the orthographic agreement signed between the Portuguese-speaking countries and the methodology for transcultural adaptation of pyshometric scales.

To assert the total prevalence of burnout, we considered suggestions made by Peterson et al. [8] and Demerouti et al. [6], who claim that mean scores $\geq 2.25$ in the dimension Exhaustion (items 1-8), and $\geq 2.1$ in Disengagement dimension (items 9-16), are considered high. Based on this, individuals were classified as shown in Table 1.

TABLE 1 - INDIVIDUALS CLASSIFICATION ACCORDING TO THE STATE OF BURNOUT, AS PROPOSED BY Peterson et al [8].

\begin{tabular}{c|c|c}
\hline \multicolumn{2}{c|}{ OLBI's Dimension } & \\
\hline Exhaustion & Disengagement & Classification \\
\hline Low & Low & Nonburnout \\
\hline Low & High & Disengaged \\
\hline High & Low & Exhausted \\
\hline High & High & Burnout \\
\hline
\end{tabular}

\section{Procedures}

Questionnaires were given to faculty members by the researcher, in their office, at a previously agreed time. Researcher did not guide and/or collaborate with questionnaire completion, thus, participants were not influenced by the researcher and were free to answer, or not, all the questions made. 


\section{Ethical Aspects}

This study was approved by the Ethics Committee in Human Research, Araraquara Faculty of Dentistry - UNESP, protocol number 33/09. Only the participants who agreed to the terms of the Free and Informed Consent participated in the study.

\section{Analysis of the psychometric qualities}

To assess the psychometric quality of the Oldenburg Burnout Inventory in this sample, an estimate the psychometric sensitivity of the items was initially carried out, for central tendency measures, variability and shape of distribution (Sk: skewness and $\mathrm{Ku}$ : kurtosis). Items with $|\mathrm{Sk}|>3$ and $|\mathrm{Ku}|>7$ were considered to have sensitivity issues [9].

Validity of the two-factor model was analyzed through a confirmatory factor analysis, using as goodness of fit indices the $\chi^{2} / \mathrm{df}, \mathrm{CFI}$ and RMSEA. Adjustment was considered appropriate when $\chi^{2} /$ $\mathrm{df} \leq 2, \quad$ CFI $>0.9, \quad$ RMSEA $<0.10 \quad$ [10]. Convergent validity was assessed through Average Variance Extracted (AVE) and composite reliability (CR), as described by Maroco [10]. The convergent validity was accepted when $\mathrm{AVE} \geq 0.5$ and $\mathrm{CR} \geq 0.7$ [11]. Discriminate validity was evaluated as proposed by Fornell, Larcker [11], and internal consistency by Cronbach's $\alpha$ coefficient.

\section{Statistical Analysis}

Descriptive statistics were performed. Prevalence of Burnout was estimated by point. To compare the mean scores of the burnout dimensions, for each variable of interest, Student's $t$ tests were performed. The significance level for decision making was $5 \%$.

\section{Results}

Participants mean age was $46.0 \pm 6.1$ years, and

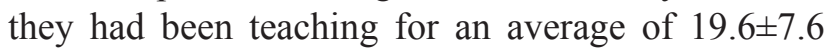
years. Data are presented in Tables 2-5, however, it is worth noticing that not all professors completed all the questions, nevertheless, this did not affect data analysis.

Table 2 presents professionals distribution according to socio-demographic characteristics.
Table 2 - Distribution (n (\%)) Of the Dentistry FACULTY REGARDING SOCIO-DEMOGRAPHIC Characteristics. Araraquara, 2010.

\begin{tabular}{|c|c|}
\hline Characteristic & n (\%) \\
\hline \multicolumn{2}{|l|}{ Gender } \\
\hline Male & $40(57.1)$ \\
\hline Female & $30(42.9)$ \\
\hline Total & $70(100.0)$ \\
\hline \multicolumn{2}{|l|}{ Time teaching } \\
\hline Until 15 years & $23(34.3)$ \\
\hline More than 15 years & $44(65.7)$ \\
\hline Total & $67(100.0)$ \\
\hline \multicolumn{2}{|c|}{ They have already taken medication due to work } \\
\hline Yes & $21(30.0)$ \\
\hline No & $49(70.0)$ \\
\hline Total & $70(100.0)$ \\
\hline \multicolumn{2}{|c|}{ They have already thought of quitting the job } \\
\hline Yes & $14(20.0)$ \\
\hline No & $56(80.0)$ \\
\hline Total & $70(100.0)$ \\
\hline \multicolumn{2}{|l|}{ Working conditions } \\
\hline Regular & $14(20.0)$ \\
\hline Good & $10(14.3)$ \\
\hline Excellent & $46(65.7)$ \\
\hline Total & $70(100.0)$ \\
\hline \multicolumn{2}{|l|}{ Working facilities } \\
\hline Regular & $10(14.9)$ \\
\hline Good & $46(68.7)$ \\
\hline Excellent & $11(16.4)$ \\
\hline Total & $67(100.0)$ \\
\hline
\end{tabular}

The sample consisted mostly of men, who had been teaching for more than 15 years. Respondent majority had never taken medication due to work nor thought of giving up teaching; however, these symptoms were present in $30.0 \%$ and $20.0 \%$ of them, respectively.

Distribution of responses to OLBI's items is shown in Table 3. It is important to clarify that one participant did not answer to questions 3 and 7-16, thus, that respondent was eliminated from the validity and the reliability analysis. 
Table 3 - Distribution (n(\%)) of the answers to OlBl's items, by the participants. Araraquara, 2010.

\begin{tabular}{|c|c|c|c|c|c|}
\hline \multirow[b]{2}{*}{ OLBI } & \multicolumn{4}{|c|}{ Answer $(\mathrm{n}(\%))$} & \multirow[b]{2}{*}{ Total } \\
\hline & $\begin{array}{l}\text { I completely } \\
\text { disagree }\end{array}$ & I disagree & I agree & $\begin{array}{l}\text { I completely } \\
\text { agree }\end{array}$ & \\
\hline $\begin{array}{l}\text { 1. There are days when I feel tired before I } \\
\text { arrive at work }\end{array}$ & 19(27.1) & $21(30.0)$ & $24(34.3)$ & $6(8.6)$ & $70(100.0)$ \\
\hline $\begin{array}{l}\text { 2. After working, I tend to need more time than } \\
\text { in the past to relax and feel better }\end{array}$ & $18(25.7)$ & $19(27.1)$ & $22(31.5)$ & $11(15.7)$ & $70(100.0)$ \\
\hline *3. I can tolerate work pressure very well & $2(2.9)$ & 16(23.2) & $35(50.7)$ & $16(23.2)$ & $69(100.0)$ \\
\hline 4. During work, I often feel emotionally drained & 19(27.1) & $34(48.6)$ & $14(20.0)$ & $3(4.3)$ & $70(100.0)$ \\
\hline $\begin{array}{l}\text { * } 5 \text {. After working, I have enough energy for my } \\
\text { leisure activities }\end{array}$ & $2(2.9)$ & $15(21.4)$ & $40(57.1)$ & 13(18.6) & $70(100.0)$ \\
\hline *6. When I work, I usually feel energized & - & $7(10.0)$ & $40(57.1)$ & $23(32.9)$ & $70(100.0)$ \\
\hline 7. After working, I usually feel worn out and weary & $18(26.1)$ & $30(43.5)$ & $16(23.2)$ & $5(7.2)$ & $69(100.0)$ \\
\hline *8. Usually, I can manage the amount of work well & $7(10.1)$ & 11(16.0) & $36(52.2)$ & $15(21.7)$ & $69(100.0)$ \\
\hline $\begin{array}{l}\text { *9. I always find new and interesting aspects in } \\
\text { my work }\end{array}$ & $1(1.4)$ & $8(11.6)$ & $33(47.9)$ & $27(39.1)$ & $69(100.0)$ \\
\hline $\begin{array}{l}\text { 10. I talk about my work in a negative way more } \\
\text { and more often. }\end{array}$ & $29(42.0)$ & $32(46.4)$ & $6(8.7)$ & $2(2.9)$ & $69(100.0)$ \\
\hline $\begin{array}{l}\text { 11. Lately, I tend to think less at work and do } \\
\text { my job almost mechanically }\end{array}$ & $28(40.6)$ & $38(55.1)$ & $1(1.4)$ & $2(2.9)$ & $69(100.0)$ \\
\hline *12. I find my work a positive challenge & $1(1.4)$ & $5(7.2)$ & $32(46.4)$ & $31(45.0)$ & $69(100.0)$ \\
\hline $\begin{array}{l}\text { 13. Over time, one can become disconnected } \\
\text { from this type of work }\end{array}$ & $38(55.1)$ & $25(36.2)$ & $4(5.8)$ & $2(2.9)$ & $69(100.0)$ \\
\hline $\begin{array}{l}\text { *14. This is the only type of work that I can } \\
\text { imagine myself doing }\end{array}$ & 14(20.3) & $17(24.6)$ & $21(30.5)$ & $17(24.6)$ & $69(100.0)$ \\
\hline *15. I feel more and more engaged in work & 14(20.3) & $17(24.6)$ & $21(30.5)$ & $17(24.6)$ & $69(100.0)$ \\
\hline 16. Sometimes I feel sickened by work tasks & $16(23.2)$ & $27(39.1)$ & $23(33.3)$ & $3(4.4)$ & $69(100.0)$ \\
\hline
\end{tabular}

* inverted items

Most professors had a positive view of their work as teachers, $91.3 \%$ agreed that their work presented a positive challenge, $86.9 \%$ said they often find new and interesting aspects in their work, and $88.4 \%$ did not often speak negatively about work. However, some signs of exhaustion were visible, given that $47.1 \%$ of teachers affirmed that lately they need more time to relax and feel better after a day's work, $26.1 \%$ were unable to withstand the work pressure, and $24.3 \%$ felt emotionally drained at work and had less energy for leisure activities after working hours.

Table 4 presents the measures to evaluate psychometric sensitivity.

Table 4 - Summary measures to characterize the PSychometric SENSItIVIty OF Oldenburg BuRnout INVENTORY ITEMS

\begin{tabular}{c|c|c|c|c|c|c|c|c}
\hline OLBI & Mean & Median & Mode & Standard-Deviation & Kurtosis & Skewness & Minimum & Maximum \\
\hline$i t 1$ & 2.24 & 2 & 3 & 0.95 & -1.03 & 0.11 & 1 & 4 \\
\hline$i t 2$ & 2.37 & 2 & 3 & 1.04 & -1.16 & 0.07 & 1 & 4 \\
\hline$i t 3$ & 2.06 & 2 & 2 & 0.76 & -0.27 & 0.31 & 1 & 4 \\
\hline$i t 4$ & 2.03 & 2 & 2 & 0.82 & -0.28 & 0.44 & 1 & 4 \\
\hline$i t 5$ & 2.07 & 2 & 2 & 0.71 & 0.33 & 0.40 & 1 & 4 \\
\hline$i t 6$ & 1.77 & 2 & 2 & 0.62 & -0.51 & 0.18 & 1 & 3 \\
\hline$i t 7$ & 2.11 & 2 & 2 & 0.88 & -0.44 & 0.44 & 1 & 4 \\
\hline$i t 8$ & 2.17 & 2 & 2 & 0.90 & -0.18 & 0.63 & 1 & 4 \\
\hline$i t 9$ & 1.76 & 2 & 2 & 0.71 & 0.17 & 0.64 & 1 & 4 \\
\hline$i t 10$ & 1.73 & 2 & 2 & 0.74 & 0.93 & 0.93 & 1 & 4 \\
\hline$i t 11$ & 1.67 & 2 & 2 & 0.65 & 2.77 & 1.10 & 1 & 4 \\
\hline$i t 12$ & 1.66 & 2 & 2 & 0.68 & 0.79 & 0.84 & 1 & 4 \\
\hline$i t 13$ & 1.57 & 1 & 1 & 0.73 & 1.84 & 1.33 & 1 & 4 \\
\hline$i t 14$ & 2.43 & 2 & 2 & 1.08 & -1.25 & 0.12 & 1 & 4 \\
\hline$i t 15$ & 1.96 & 2 & 2 & 0.69 & -0.85 & 0.06 & 1 & 3 \\
\hline$i t 16$ & 2.20 & 2 & 2 & 0.84 & -0.82 & 0.05 & 1 & 4
\end{tabular}


There were no significant normality issues ( $\mathrm{Sk}=0$, $\mathrm{Ku}=0$ ), except for item 11 that was slightly leptokurtic, but without compromising the psychometric sensitivity.

The fit of bi-factorial model for OLBI was bad $(\chi 2)$ $\mathrm{df}=1.586, \mathrm{CFI}=0.821, \mathrm{GFI}=0.786, \mathrm{RMSEA}=0.093$ ) given that items 11 and 14 had factor weights below the required value $(\lambda<0.50)$, and items 6 and 15 were correlated to two of the instrument dimensions, which was verified by the modification indices. Thus, these items were eliminated, and a new model's adjustment can be considered good $\left(\chi^{2} / \mathrm{df}=1.205, \mathrm{CFI}=0.954\right.$, GFI $=0.876$, RMSEA $=0.055$ ). The convergent (AVE: $0.37-0.42)$ and discriminant validity $\left(\rho^{2}=0.41\right)$ were inadequate. There was good composite reliability (CR: 0.75-0.83) and internal consistency ( $\alpha$ : 0.75$0.84)$.

The prevalence of burnout can be observed in Figure 1.

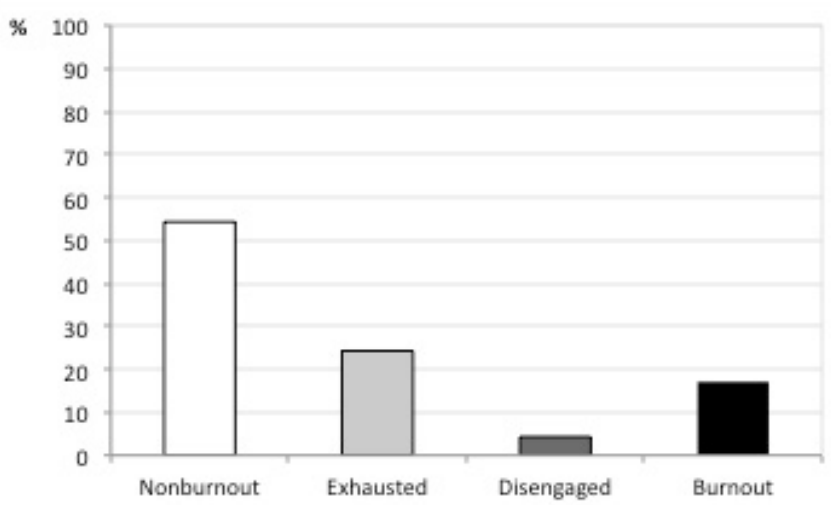

Figure 1 - Prevalence of Burnout in the evaluated teachers. Araraquara 2010.

It is noteworthy that $54.3 \%$ of the participants did not present burnout syndrome or associated symptoms. However, there was a prevalence of the syndrome in $17 \%$ of participants.

The mean score of Exhaustion was $0.61 \pm 2.11$ $(\mathrm{IC} 95 \%=1.97-2.25)$ and the score of Disengagement was $1.73 \pm 0.50 \quad($ IC95\% $=1.61$ to 1.85$)$. Taking into account that scale values range between 1-4, obtained levels were low in both dimensions, in the sample.

Comparisons between mean scores obtained with OLBI, according to variables of interest, are presented in Table 5.
Table 5 - Mean and standard deviation (SD) of Exhaustion and Disengagement pResented BY PROFESSORS, ACCORDING TO VARIABLES OF interest. Araraquara, 2010.

\begin{tabular}{|c|c|c|c|c|c|}
\hline \multirow[b]{2}{*}{ Variable } & \multirow[b]{2}{*}{$\mathrm{n}$} & \multicolumn{2}{|l|}{ Exhaustion } & \multicolumn{2}{|c|}{ Disengagement } \\
\hline & & mean $\pm S D$ & $\mathrm{p}$ & mean $\pm S D$ & $\mathrm{p}$ \\
\hline \multicolumn{6}{|l|}{ Gender } \\
\hline Male & 40 & $1.99 \pm 0.61$ & & $1.70 \pm 0.53$ & \\
\hline Female & 30 & $2.27 \pm 0.58$ & $0.049^{*}$ & $1.77 \pm 0.47$ & 0.580 \\
\hline \multicolumn{6}{|c|}{$\begin{array}{l}\text { They have } \\
\text { already taken } \\
\text { medication } \\
\text { due to work }\end{array}$} \\
\hline Yes & 15 & $2.40 \pm 0.57$ & & $1.85 \pm 0.47$ & \\
\hline No & 49 & $1.94 \pm 0.56$ & $0.008^{*}$ & $1.70 \pm 0.53$ & 0.312 \\
\hline \multicolumn{6}{|c|}{$\begin{array}{l}\text { They have } \\
\text { already } \\
\text { thought of } \\
\text { quitting the } \\
\text { job }\end{array}$} \\
\hline Yes & 13 & $2.58 \pm 0.59$ & & $1.94 \pm 0.40$ & \\
\hline No & 56 & $1.98 \pm 0.56$ & $0.001^{*}$ & $1.68 \pm 0.51$ & 0.093 \\
\hline \multicolumn{6}{|c|}{ Time teaching } \\
\hline$\leq 15$ years & 26 & $2.16 \pm 0.60$ & & $1.70 \pm 0.41$ & \\
\hline$>15$ years & 44 & $2.08 \pm 0.63$ & 0.599 & $1.75 \pm 0.55$ & 0.663 \\
\hline
\end{tabular}

*significant statistical difference for $\alpha=0.05$

Statistically significant differences are observed in Exhaustion mean scores according to gender, being that women presented higher values. Participants who reported taking medication due to work also had a higher mean score of Exhaustion ( $\mathrm{p}=0.008$ ), as well as those who had thought about quitting teaching profession $(\mathrm{p}=0.001)$.

\section{Discussion}

The importance of studies on burnout syndrome is supported by lack of motivation and impaired occupational health $[3,8,12-16]$. They are caused by occupational stress, which may reflect directly on the productivity and quality of the work performed, causing losses that can impact on all higher education levels.

Burnout does not appear abruptly, but is the final stage of a process, leading to symptoms related to the syndrome dimensions [12]. This knowledge is strategic and enables periodic screening studies for Burnout Syndrome among teachers. Thus, a better understanding of burnout enables the creation of prevention and treatment actions for the syndrome 
and associated symptoms. Although it is not within this project scope, it is worth mentioning that the strategies for Burnout prevention/intervention are of a psychosocial nature. They can be implemented in the short, medium and long term, and may include different individual and organizational aspects.

It is noteworthy that this cross-sectional study design does not allow the establishment cause and effect relation between variables, however, associations of interest, that may be important to identify risk groups, can be explored [17]. In this study, there was no intention to detail professor teaching activities (i.e., type of classes taught, workload, specific features of their work), given that in a first moment we sought only to identify the prevalence of syndrome and its association with the main features of interest, in order to be able to determine its impact on teachers; however, this detail should be explored in future studies.

The results of the Burnout Syndrome prevalence $(17.1 \%)$ corroborate those of other studies present the literature, such as that by Vasconcelos et al. [16], who found a prevalence of $18.29 \%$ in middle school teachers, from both public and private schools in Maringá - PR.

Levy, et al. [15] evaluated 77 middle school teachers, from public schools in Rio de Janeiro, and found that $70.13 \%$ of the teachers had some symptom of the syndrome. These results are more alarming than those observed in this study. Levy et al. [15] justify this data stating that teachers are subjected to many discomforts, arising from occupational characteristics activity, which becomes more and more dehumanized due to progressive profession depreciation.

A direct comparison of prevalence should be made with caution, since the studies used different inventories and/or cut-off points for screening of the syndrome. Furthermore, the studies presented above were conducted with teachers of elementary and middle school, whose reality is often different from that in higher education. Despite the inherent differences in instruction level, it is believed that teaching performance core is maintained regardless of their activity level.

On Table 3 it is noted that most faculty members have a positive view of their profession, however, some fatigue and exhaustion signs are evident in some responses to the inventory, which provide evidence of exhaustion, but not necessarily the existence of burnout.

On Table 5 a higher mean score of Exhaustion can be observed in women. Similar results were found by Vasconcelos et al. [16], who justify their findings based on the doubled work, and on conflict between work and family, which is usually more pronounced in women. Ogeda et al. [13] adds that this functional duality can create anguish caused by the accumulation of activities and the paradox between the work and family and children's needs.

Teachers who reported taking medication and who had thought about quitting teaching presented greater levels of Exhaustion, which can be attributed to fatigue, probably due to a high workload, the competitive academic environment and the lack of time for family and leisure. Moreno-Jimenez et al. [12] conducted a study with 885 university professors from three universities in Spain, linking burnout effects to: interpersonal conflict, intention to stop teaching, and other factors related to the syndrome. The results confirmed the hypothesis that both emotional Exhaustion and Disengagement are a reflection of everyday demands and conflicts that directly influence the intention to stop teaching.

Another important aspect to emphasize is that adherence rate to this survey was $71 \%$ and that most teachers who refused to answer the inventory claimed lack of time, which certainly could have influenced the results presented.

Therefore, studies aimed at detecting burnout syndrome are of paramount importance for development of prevention and intervention programs, which may reflect occupational health maintenance, consequently improving productivity and services provided by the worker.

\section{Conclusion}

We observed a $17.1 \%$ prevalence of Burnout among faculty members evaluated, and the scores of exhaustion were significantly higher: among women, among those who reported taking medication due to work, as well as those who have considered stop teaching. 


\section{Resumo}

A Síndrome de Burnout é considerada um problema psicossocial a que os professores estão rotineiramente expostos. Realizou-se este estudo com o objetivo de estimar a prevalência da Síndrome de Burnout em professores de Odontologia e sua relação com características socio-demográficas de interesse. Participaram 70 professores do curso de graduação em Odontologia da Faculdade de Odontologia de Araraquara - UNESP. Utilizou-se o Inventário de Burnout de Oldenburg (OLBI). A prevalência de Burnout foi estimada por ponto e para comparação dos escores médios das dimensões do Burnout para cada variável de interesse foi realizado o teste $t$ de Student. O nível de significância foi de $5 \%$. A média de idade dos

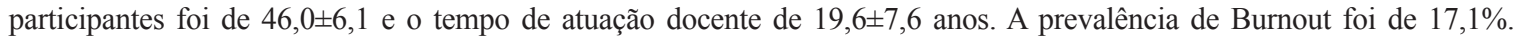
Observou-se baixos escores médios de Exaustão $(2,11 \pm 0,61)$ e de Distanciamento $(1,73 \pm 0,50)$. Na dimensão exaustão, houve diferença estatisticamente significante entre o gênero $(\mathrm{p}=0,049)$, entre os participantes que relataram ingerir medicação devido ao trabalho $(\mathrm{p}=0,008)$ e os que já pensaram em desistir da docência $(\mathrm{p}=0,001)$. Não houve diferença estatisticamente significante nos escores de Exaustão segundo o tempo de atuação docente e nos escores de Distanciamento de acordo com o gênero, o costume de ingerir medicação e o tempo de atuação na profissão.

\section{PalaVRas-chave}

Saúde ocupacional; esgotamento profissional; odontologia; professores; saúde pública.

\section{References}

1. Maslach C, Jackson SE. The measurement of experienced burnout. J Occup Behavior. 1981;2(2):99-113.

2. Maslach C, Schaufeli WB, Leiter MP. Job burnout. Annu Rev Psychol. 2001;52:397-422.

3. Carlotto MS. Síndrome de burnout: o estresse ocupacional do professor. Canoas: ULBRA; 2010. 192 p.

4. Chambers R, Belcher J. Comparison of the health and lifestyle of general practitioners and teacher. Br J Gen Pract. 1992;43(374):378-82.

5. Griffith J, Steptoe A, Cropley M. An investigation of coping strategies associated with job stress in teachers. Br J Educat Psychol. 1999;69(4):517-31.

6. Demerouti E, Bakker AB, Nachreiner F, Schaufeli WB. The job demands-resources model of burnout. J Appl Psychol. 2001;86(3):499-512.

7. Campos JADB, Zucoloto ML, Bonafé FSS, Jordani PC, Maroco J. Reliability and Validity of self reported burnout in college students: a cross randomized comparison of penciland-paper vs. online administration. Computers in Human Behavior. 2011;27(5):1875-83.

8. Peterson U, Demerouti E, Bergstrom G, Asberg M, Nygren A. Work characteristics and sickness absence in burnout and nonburnout groups: a study of Swedish health care workers. Int J Stress Manag. 2008;15(2):20.

9. Kline RB. Principles and practice of structural equation modeling. New York: The Guilford Press; 1998. 354 p.

10. Maroco J. Análise de equações estruturais. Lisboa: ReportNumber; 2010. 374 p.

11. Fornell C, Larcker DF. evaluating structural equation models with unobservable variables and measurement error. J Marketing Res. 1981;18(1):39-50.

12. Moreno-Jimenez B, Garrosa-Hernandez E, Gálvez M, González JL, Benevides-Pereira AMT. A avaliação do burnout em professores. Comparação de instrumentos: CBP-R e MBI-ED. Psicol Estud. 2002;7(1):11-9.

13. Ogeda CRD, Pedrozo DM, Dallagrana ET, Santos R. Burnout em professores: a síndrome do século XXI. Rev Eletrônica Ciênc Educ. 2003;1(2):3-19.

14. Carlotto MS, Camara SG. Análise da produção cientí- fica sobre a Síndrome de Burnout no Brasil. Psico-USF. 2008;39(2):7.

15. Levy GCTdM, Sobrinho FdPN, de Souza CAA. Síndrome de Burnout em professores da rede pública. Produção. 2009;19(3):458-65.

16. Vasconcelos FF, Granado IE, Martins Junior J. Estudo comparativo sobre a incidência da Síndrome de Burnout em professores da rede pública e privada de Maringá - PR. Saúde Pesqui. 2009;2(1):23-6.

17. Campos JADB, Trotta OST, Bonafé FSS, Maroco J. Burnout em dentistas do serviço público: ter ou não ter, eis a questão! Rev Odontol da UNESP. 2010;39(2):109-14.

Received : 06/10/2011

Accepted: 15/05/2012

Corresponding author: Juliana Álvares Duarte Bonini Campos Rua Humaitá n.1680, Centro - Araraquara - SP Cep: 14801-050 jucampos@foar.unesp.br 